\title{
Elektroeğrilmiş Nanoliflerin İlaç Taşıyıcı Sistem Olarak ve Doku Mühendisliğinde Kullanımı
}

\author{
Bürde Süheyla Sunar, Canan Hasçiçek
}

öz

Uzunlukları çaplarına kıyasla oldukça fazla olan nanolifler, sahip oldukları yüksek yüzey/hacim oranı ile ilaç taşıyıcı sistemler ve doku mühendisliği de dahil olmak üzere birçok alanda kullanım potansiyeline sahiptir. Farklı yöntemlerle üretilme imkanı olan nanoliflerin en cazip üretim metodu elektroeğirme yöntemidir. $\mathrm{Bu}$ yöntemle üretilen nanoliflerin fizikokimyasal özellikleri; uygulanan voltaj, polimer çözeltisinin akış hızı, kapiller ve kolektör arasındaki mesafe, polimerin fizikokimyasal özellikleri ve kullanılan çözücü gibi birçok parametreden etkilenmektedir. Elektroeğrilmiş nanoliflerin etkin madde salım özellikleri, etkin maddenin difüzyonu ve taşıyıcı polimerin degredasyonu ile belirlenmektedir. Ayrıca nanoliflerin etkin madde salım özelliklerini lifin matriks veya depo yapısında olması, yüzeyinde aktif bileșenlerin bulunması etkilemektedir. Sahip olduğu fiziksel özellikler nedeniyle nanolifler, hücrelerin fizyolojik çevresini taklit etmek amacıyla yapay ekstraselüler matriksler geliştirilerek doku ve organların rejenerasyonunu ya da üretimini hedefleyen doku mühendisliği alanında kullanımı için oldukça elverişlidir. $\mathrm{Bu}$ amaçla nanoliflerin yüzey özellikleri değiştirilerek biyobenzer yapılar elde edilebilmektedir. Nanolifler, etkin maddenin hedeflenen salım profilini sağlaması ve biyobenzer özellik kazanarak doku mühendisliğinde kullanımına imkan vermesi ile gelecek vaat eden sistemlerdir.

Anahtar kelimeler: Biyobenzer, doku mühendisliği, elektroeğirme, ilaç taşıyıcı sistem, nanolif
Bürde Süheyla Sunar

Karadeniz Teknik Üniversitesi, Eczacıllk Fakültesi, Farmasötik Teknoloji Anabilim Dall, Trabzon 61080 Türkiye

Canan Hasçiçek

Ankara Üniversitesi, Eczacıllk Fakültesi, Farmasötik Teknoloji Anabilim Dall, Tandoğan, Ankara 06100 Türkiye

Sorumlu Yazar:

Canan Hasçiçek

e-posta:cogan@pharmacy.ankara.edu.tr

Submitted / Gönderilme: 14.11.2016

Accepted / Kabul: $\quad 22.02 .2017$
Revised / Düzeltme: 18.02 .2017

\section{GİRIŞ}

Nanolifler, çapları 1 mm'den daha az ve uzunlukları çaplarına kıyasla oldukça fazla olan ipliksi yapılardır $(1,2)$. Lif çapının nanometre boyutuna düşmesiyle; fiziksel, kimyasal ve biyolojik özellikleri oldukça gelişmiş, düşük porozitesi ve yüksek yüzey alanına sahip nanolifler ortaya çıkmıştır. Nanolifler kendilerine özgü yüksek yüzey alanı/hacim oranı ile mevcut teknolojiyi geliştirme ve yeni alanlarda kullanılma potansiyeline sahiptir. Nanolifler Şekil 1' de gösterildiği gibi güçlendirilmiş kompozit yapımı, koruyucu kıyafetler, filtrasyon uygulamaları, biyomedikal araçlar, elektriksel ve optik uygulamalar, nanosensörler, doku mühendisliği ve kontrollü etkin madde salımı gibi çok çeşitli alanlarda kullanım potansiyeline sahiptir $(3,4)$.

Terapötik etkinin artırılması ve konvensiyonel dozaj formlarının toksitelerinin azaltılması için liposomlar, polimerik miseller, nanopartiküller gibi birçok ilaç taşıyıcı sistem geliştirilmiştir. Bu sistemlere kıyasla nanolifler daha 
geniş materyal ve etkin madde seçim olanağ sağlamaktadır. Ayrıca lif bileşimi ve üretim tekniği değiştirilerek istenilen etkin madde salım kinetiğini elde etme imkanı sunmaktadır. Yüksek yüzey alanı/hacim oranı, yüksek enkapsülasyon etkinliği, tekrarlanabilir etkin madde salımı, uygulama kolaylığı, düşük maliyet gibi birçok cazip özelliğe sahip olan nanolifler, özellikle yara örtücü materyal ve cerrahi operasyon sonrası lokal kemoterapide etkin madde salımı için tercih edilmektedir $(5,6)$.

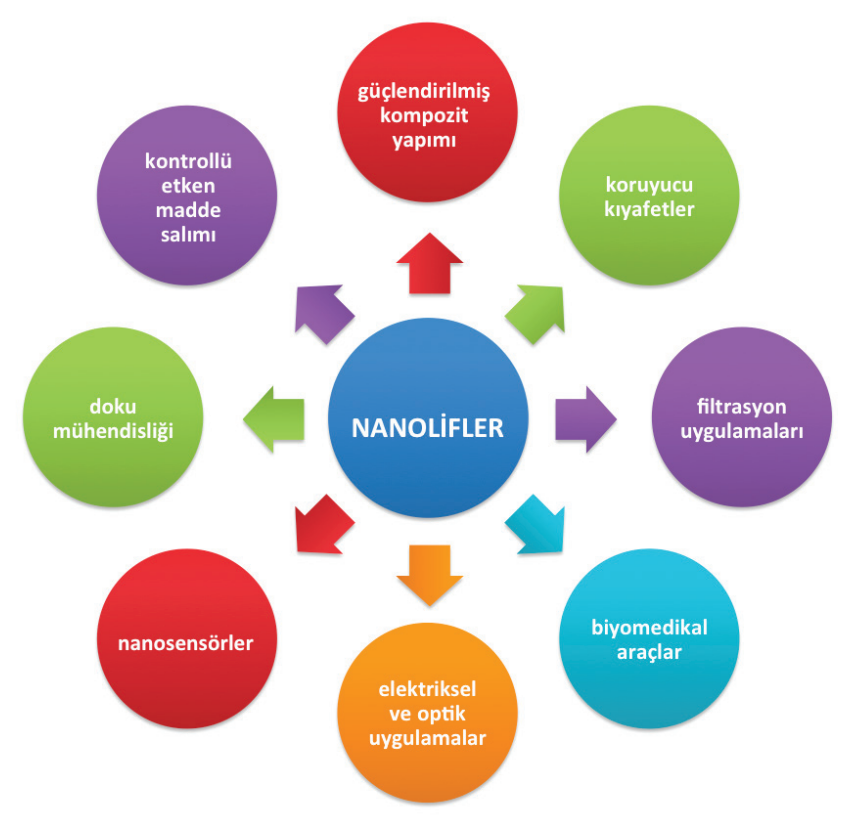

Şekil 1. Nanoliflerin kullanım alanları $(3,4)$.

İlaç taşıyıcı sistem olarak kullanılan nanolifler, cazip özellikleri nedeniyle doku mühendisliğinde de kullanım alanına sahiptir. Yüksek yüzey alanı/hacim oranına sahip nanolifler, nanopartiküler sistemlere göre organizma ile daha fazla biyobenzerlik göstererek, doku mühendisliğinde kullanılan hücrelerin canlılığını sürdürebilmesi için daha elverişli bir ortam sağlamaktadır. Ayrıca nanolif yüzeyinin modifiye edilebilir olması, bu potansiyelini artırmaktadır. Nanoliflerin bu alanda kullanılmasının bir başka sebebi ise mekanik olarak dayanıklı ve esnek bir yapıya sahip olmasıdır. Taşıdığı bu özellik sayesinde implantasyon işlemi için oldukça uygun bir yapı sergiler $(7,8)$.

Nanolif elde etmek için birçok teknik denenmiştir. Özellikle doku mühendisliği ve etkin madde salımında kullanılan nanolifler; kendiliğinden birleşme (selfassembly), faz ayrışması ve elektroeğirme yöntemleriyle elde edilirler. Kendiliğinden birleşme yönteminde, rastgele bir arada bulunan bileșenler kovalent olmayan bağlarla düzenli ve stabil bir yapı oluştururlar. Bu yöntemde peptit ve proteinlerin jelleşme özelliklerinden faydalanılarak nanolif oluşumu gerçekleştirilmektedir ve sıklıkla $L$-/ $D$ - peptit türevleri bu amaçla kullanılmaktadır (9, 10). Peptit ve proteinler dişında kendiliğinden oluşma yönteminde polisakkaritler gibi polimerik maddelerden de faydalanılabilmektedir. Yapılan bir çalışmada paklitaksel ve dekstran kullanılarak lif yapısı elde edilmiştir. Dekstranın yapisında bulunan fazla miktardaki hidroksil grupları ile paklitaksel molekülleri arasında hidrojen bağları, hidrofilik ve hidrofobik etkileşimler gibi güçlü çekim kuvvetleri oluşmasından faydalanılarak lif yapısı elde edilmiştir (11). Faz ayrışması metodunda ise, polimer çözeltisi termodinamik ayrılma sonucunda polimerce zengin ve polimerce fakir olacak şekilde fazlara ayrışır. Polimerik madde çözeltisinde gerçekleşen faz ayrışması, termal indüklenme ya da polimerik maddeyi çözmeyen bir çözücünün polimer çözeltisine ilave edilmesi gibi etkenlerden dolayı jel oluşumu gözlenir. Daha sonra jelden çözücü uzaklaştırılır ve jel, polimer camsı geçiş sıcaklığının altına kadar soğutulur. Son olarak vakum altında dondurularak kurutulur ve nanolif ağ elde edilir. Faz ayrışması metodu ile nanolif elde edilen bir çalışmada, poli3-hidroksibütirat (PHB) kloroform içerisinde çözülmüş ve daha sonra tetrahidrofuran gibi PHB'yi çözmeyen ama klorofomla karışabilen bir çözücü ortama eklenmiştir. Ortama tetrahidrofuran eklenmesinden sonra lif ağının oluşumu gerçekleşmiştir. Son basamakta ise yıkama işlemi yapılarak $-130^{\circ} \mathrm{C}$ 'de dondurulmuş ve liyafilizatörde 2 gün boyunca kurutulmuştur (12). Ancak kendiliğinden birleşme ve faz ayrışması metotlarında sınırlı sayıdaki polimerin kullanılması, sadece laboratuvar ölçeğinde üretim yapılabilmesi ve düşük verim elde edilmesi gibi istenmeyen nedenlerden dolayı elektroeğirme yöntemi daha cazip hale gelmiştir $(5,13)$.

Yapmış olduğumuz bu derleme çalışmasında elektroeğrilmiş nanolif özellikleri ve üretim tekniği, ilaç taşıyıcı sistem olarak ve doku mühendisliği alanlarındaki kullanımları, elektroeğrilmiş nanolifler üzerinde yapılan in vitro analizler ile elektroeğrilmiş nanoliflerin sterilizasyon seçenekleri üzerinde durulmuştur.

\section{ELEKTROEĞRILMIŞ NANOLIFLER}

Lif üretiminde elektrostatik kuvvetler yüz yılı aşkın süredir kullanılmaktadır ve ilk kez 1934 yllında patentlenmiştir. Elektroeğirme olarak bilinen bu yöntem, kapillerdeki polimer çözeltisi ve metal kolektörün yüksek voltaj kaynağ 
aracılığıyla zıt elektrik yükü ile yüklenmesi temeline dayanır ve polimer çözeltisine uygulanan yüksek elektrik akımı ile çözeltinin yüzey özellikleri değiştirilerek nanometre veya mikrometre boyutlarında lifler elde edilmektedir. Elektroeğirme yönteminde doğal ve sentetik (biyobozunur ve biyobozunur olmayan) polimerler veya polimer karışımları kullanılmaktadır ve poli-e-kaprolakton (PCL), poli(L-laktik asit) (PLLA), poli(L-laktik-ko-kaprolakton) (PLCL), poli( $D, L$-laktik-ko-glikolik asit) (PLGA), polietilenglikol (PEG) en sık kullanılan polimerlerdir. Etkin madde olarak ise, özellikle antineoplastik ilaçlar, antibiyotikler, proteinler, DNA ve RNA nanolif sistemlerde kullanılmaktadır $(5,6)$.

Elektroeğirme yöntemi; yüksek yükleme kapasitesi, yüksek enkapsülasyon etkinliği, uygulama kolaylığı, çoğu sentetik ve doğal polimer ile çalışma imkanı, birkaç nanometreden mikrometreye kadar değișen boyutlarda lif eldesi, mekanik olarak dayanıklı ve esnek lif eldesi, tektür lif elde edildiği için saflaştırma işlemine gerek duyulmaması, iki ya da üç boyutlu lif eldesi, birkaç santimetreden metre boyutlarına kadar oldukça uzun lif eldesi, düşük maliyet gibi birçok avantaja sahiptir $(1,5,8,13)$. Ancak elektroeğirme yöntemi kullanım kolaylığı sağlamasına rağmen, stabil olmayan jet oluşumu ve birçok parametrenin lif oluşumunu ve yapısını önemli ölçüde etkilemesi yöntemin dezavantajı olarak sayllabilir $(1,6)$.

Elektroeğirme sisteminin ana bileşenlerini Şekil 2' de gösterildiği gibi yüksek elektrik kaynağı, etkin madde içeren polimer çözeltisinin bulunduğu enjektör ve enjektör pompası ile metal kolektör oluşturmaktadır. Sistemin işleyişi ise şu şekildedir: Polimer çözeltisi ya da emülsiyonu enjektöre konur. Enjektör iğnesine 1-30 kV arasında elektrik uygulandığında polimer damlacıkları elektrik yüklenir. Zıt yüklü polimer çözeltisi ve kolektör arasındaki çekim kuvvetlerinin etkisiyle ve çözeltideki aynı yüklerin birbirini itmesiyle, kapillerde asılı duran damlacı̆̆ın yuvarlak ucu bir koni (Taylor konisi) halini alır. Uygulanan elektrik alan kuvveti çözeltinin yüzey gerilimini aştığı zaman, lif Taylor konisinden ejekte olmaya başlar. Daha sonra ise lif kolektöre doğru hareket ederken çözeltideki çözücüler buharlaşır ve katı lifler kolektörde toplanır $(5,6)$.

Elektroeğirme yönteminde kapillere uygulanan voltaj, polimer çözeltisinin akış hızı, kapiller ile kolektör arasındaki mesafe, çözelti konsantrasyonu, polimerin molekül ağırlığı, çözeltinin viskozitesi ve yüzey gerilimi, çözücü seçimi, çözeltinin iletkenliği gibi birçok parametre lif oluşumu ve morfolojisi üzerine etkilidir.

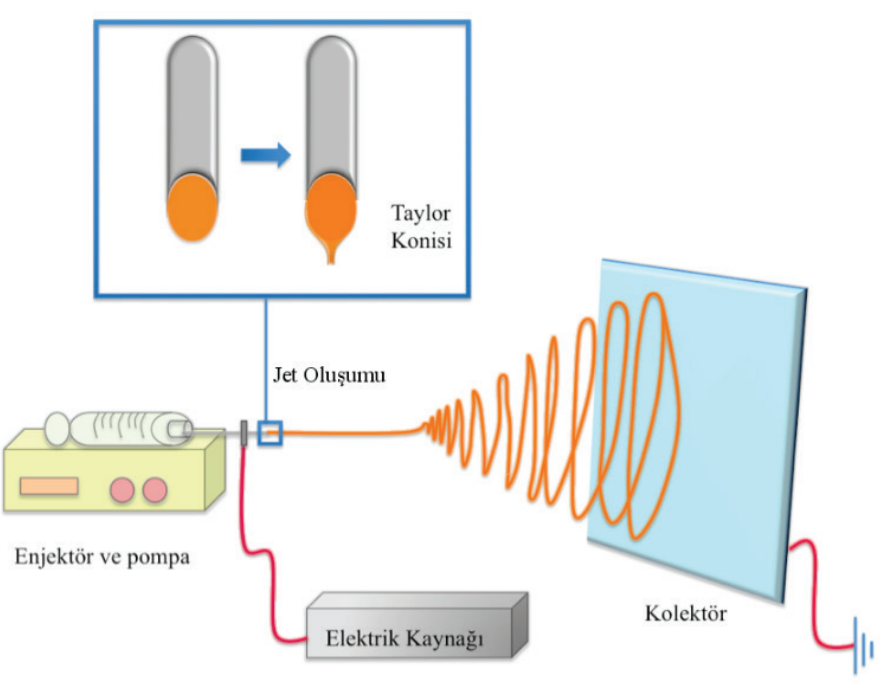

Şekil 2. Elektroeğirme sistemi bileşenleri $(5,6)$.

\section{İSLEM PARAMETRELERI}

\section{Kapillere Uygulanan Voltaj}

Elektroeğirme işleminde kapillerdeki çözeltiye uygulanan voltaj çok önemli bir parametredir ve sadece belirli bir eşik değerin üzerindeki voltajda lif oluşumu gözlenir $(6,14)$. Ancak voltajın lif boyutuna etkisi üzerine farklı görüşler mevcuttur. Yapılan çalışmalar sonucunda araştırmacılar; değişen voltajın etkisiyle Taylor konisinin şeklinin değiştiğini (15), voltajın lif çapı üzerinde çok etkili olmadığını (16), yüksek voltajla kapillerden daha fazla çözeltinin ejekte olduğunu ve lif çapının $\operatorname{arttı̆̆ını~}(17,18)$, artan voltajın lif çapını azalttığını ve çözücünün daha çabuk buharlaştığını $(15,19,20)$, çok düşük ve yüksek voltaj değerlerinde ince uzun lifsi yapılar yerine yer yer gözlenen istenmeyen boncuksu kalınlaşmaların oluştuğunu $(15,18-$ 20) ifade etmişlerdir.

\section{Polimer Çözeltisinin Akış Hızı}

Polimer çözeltisinin akış hızı; lifin çapını, porozitesini ve şeklini etkilemektedir. Taylor ve ark. yaptıkları bir çalışmada; eğer kapillere gelen çözelti akışı, lif jet olarak ayrılan çözeltinin yerini almak için yeterli oranda değilse kapiller ucundaki koninin şeklini koruyamadığını fark etmiştir (21). Polistren ile yapılan çalışmalarda ise akış hızının artışı ile lif ve por çaplarının arttığı gözlemlenmiştir $(19,22)$. Ayrıca yüksek akış hızı sonucu lifin kolektöre ulaşmadan önce uygun kuruma zamanının olmaması nedeniyle boncuklu lifler görülmüştür (23-25). 


\section{Kapiller-Kolektör Arasındaki Mesafe}

Lif çapı ve morfolojisini kontrol altında tutmak için incelenen yaklaşımlardan bir tanesi de kapiller ve kolektör arasındaki mesafedir. Liflerin kolektöre ulaşmadan önce kurumaları için yeterli zamanı sağlayan minimum mesafenin gerekli olduğu bulunmuştur. Mesafenin gerekenden daha kısa veya uzun olması durumunda ise, boncuklu lifler gözlemlenmiştir $(26,27)$. Başka bir çalışmada ise Taylor konisi ile kolektör arasındaki mesafenin artması ile lif çapının azaldığı belirtilmiştir (28). Bu nedenlerden dolayı kolektör ile kapiller arasındaki en uygun mesafe belirlenmelidir.

\section{POLIMMER ÇÖZELTİSINE AİT PARAMETRELER}

İşlem parametrelerine ilave olarak polimer çözeltisine ait birçok parametre lif oluşumunda ve morfolojisinde etkilidir.

\section{Kapillerdeki Çözelti Konsantrasyonu}

Kapillerden püskürtülen çözelti konsantrasyonu, lifin oluşup oluşamayacağını belirler. Nanolif oluşumu için polimer zincirlerinin birbirlerine dolanması gerekir ve polimer çözeltisi de bu dolanmanın gerçekleşebilmesi için yeterli konsantrasyonda olmalıdır. Eğer çözelti çok dilüe olursa o zaman polimerik lif kolektöre ulaşamadan yüzey geriliminin etkisiyle kopar, çözelti çok konsantre olursa yüksek viskoziteden dolayı kapillerdeki çözeltinin akış hızı kontrol edilmesi zorlaşır ve lif oluşumu gözlenmez. Polimer konsantrasyonu çözeltinin viskozitesini ve yüzey gerilimini de etkilemektedir ki bu parametreler elektroeğirme işlemi için çok önemlidir (28). Polimer çözeltisinin konsantrasyonu arttıkça lif çapının da büyüdügü belirlenmiştir $(26,29)$.

\section{Polimerin Molekül Ağırlığı}

Molekül ağırlığı polimerin viskozite, yüzey gelirimi, iletkenlik ve dielektrik kuvveti gibi birçok reolojik ve elektiriksel özelliğini etkilediği için molekül ağırlığı, lif morfolojisi üzerine etkili olan önemli bir parametredir. Genellikle yüksek molekül ağırlıklı polimer çözeltileri, lif oluşumu için arzu edilen viskoziteyi sağlamak için kullanılırlar. Yapılan çalışmalar çok düşük molekül ağırlıklı polimerlerin kullanılması sonucunda boncuklu liflerin ve yüksek molekül ağırlıklı polimerlerin kullanılması ile de daha büyük çaplı liflerin oluştuğunu göstermiştir $(20,30)$.

Polimerin molekül ağırlığı, çözeltideki polimer zincirlerin birbirine dolanması dolayısıyla çözelti viskozitesini belirler.
Bunun için düşük polimer konsantrasyonlarında bile, PLLA (yüksek molekül ağırlıklı) gibi polimerler yeterli zincir dolanmasını sağlayabilir ve uniform jet elde edebilmek için yeterli olan viskozite seviyesi sağlanmış olur (30).

\section{Kapillerdeki Çözeltinin Viskozitesi}

Çözeltiviskozitesinin;lif morfolojisi, çapve uzunluğu üzerinde önemli etkileri vardır. Çok düşük viskozite değerlerinde kısa lifler oluşurken, çok yüksek viskozitede polimer çözeltisinden jetin çıkışı güçleşir. Çözelti viskozitesinin artışı ile daha büyük ve uniform çaplı lifler elde edilmektedir $(14,15)$. Bu nedenlerden dolayı, elektroeğirme işlemi için çözelti viskozitesini optimize etmek gerekmektedir.

\section{Kapillerdeki Çözeltinin Yüzey Gerilimi}

Yüzey gerilimi, büyük olasılıkla çözeltinin çözücü bileşiminin bir fonksiyonu olarak elektroeğirme işleminde kritik rol oynar. Çözeltinin yüzey gerilimi azaltılarak boncuksuz lifler elde edilebilir. Genellikle yüksek yüzey gerilimi, elektroeğirme işlemini stabil olmayan jet oluşumu ve püskürtülen damlacıkların oluşması nedeniyle engellemektedir (31).

\section{Çözücü Seçimi}

Çözücü seçimi, lif porozitesi ve lifin oluşumu üzerinde oldukça kritik bir öneme sahiptir. Kapiller ve kolektör arasında yeterli çözücü buharlaşmasının sağlanabilmesi için mutlaka etanol, metanol, kloroform, aseton, dimetil formamit, dimetil sülfoksit, dimetil asetamit ve heksafloro2-propanol gibi uçucu çözücüler, bu çözücülerin birbirleri ile karışımları ya da bu çözücülerin sulu karışımları kullanılmalıdır (8, 32-38). Lif jet kapillerden kolektöre doğru hareket ederken, katı polimer lifler kolektörde toplanmadan önce faz ayrılması meydana gelir ve bu süreç çözücünün uçuculuğundan oldukça etkilenmektedir (6). Megelski ve arkadaşları, çözücü uçuculuğunun lif yüzeyinin porozitesi üzerinde de etkili olduğunu göstermiştir. Uçuculuğu yüksek çözücüler, yüzeyi porlu lif eldesine neden olabilmektedir (19).

\section{Kapillerdeki Çözeltinin İletkenliği}

Birkaç yalıtkan polimer dışında, polimerlerin çoğu iletken özelliktedir ve polimer çözeltisinde yüklenen iyonlar jet oluşumunda oldukça önemlidir. Çözelti iletkenliği; başlıca polimer tipi, kullanılan çözücü, iyonlaşabilen tuzların 
varlığg ile belirlenmektedir. Çözeltinin elektrik iletkenliğinin artışı ile elektroeğrilmiş nanolif çapında önemli bir düşüş gerçekleşir. İletkenliği düşük çözeltilerde ise jetin yetersiz uzanımı sonucu boncuklar görülebilir. Hayati ve ark., iletkenliği yüksek çözeltilerin yüksek elektrik alan varlığında uniform lif eldesinin zorlaştığını ve bu durumun geniş çap dağılımı yanında yüksek kırılganlığa da yol açtığını öne sürmüşlerdir (39).

\section{FORMÜLASYONA AİT PARAMETRELER}

Elektroeğrilmiş nanolif formülasyonlarının ürün kalitesi üzerine polimer tipi, polimer bileşimi, polimer konsantrasyonu, etkin madde tipi ve konsantrasyonu, etkin madde-polimer oranı, sürfaktan tipi ve konsantrasyonu gibi birçok parametrenin etkisi vardır. Elektroeğrilmiş nanoliflerin morfolojik özellikleri üzerine polimer bileşiminin ve etkin madde-polimer oranının etkisinin incelendiği bir çalışmada Eudragit S100 ve Eudragit RS100 polimerleri 20:80, 60:40 ve 100:0 oranlarında \% 25 a/h'lik çözeltileri kullanılarak nanolif üretimi yapılmış ve nanolif yapısındaki Eudragit S100 oranının artışı ile viskozitede bir artışın gerçekleştiği ve bunun sonucunda daha geniş çaplı ve düzgün yüzeyli lifler elde edildiği görülmüştür. Etkin madde:polimer oranı ise 1:1, 1.5:1, 2:1 ve 2.5:1 oranlarında incelenmiş ve lif oluşumu için en uygun oranların 1.5:1 ve 2:1 olduğu belirlenmiştir (40). Jahangiri ve ark., yapmış oldukları çalışmada triamsinolon asetonidin PLGA nanolifleri üzerine etkin madde:polimer oranı ve polimer çözeltisinin konsantrasyonlarının etkisini incelemişlerdir. Etkin madde:polimer oranı 1:5 ve 1:10 olacak şekilde belirlenmiş ve bu oranlarda \%10, 15 ve 20 a/h konsantrasyonlarında etkin madde-polimer çözeltileri hazırlanmıștır. Etkin madde:polimer oranı 1:5 ve \% 10 ve 20 konsantrasyonlarında nanolif ağ yapısında 50 ile $100 \mathrm{~nm}$ arasında değişen boncuk yapıları gözlenmiştir. Etkin madde:polimer oranı 1:10 olduğunda ve \% 20 konsantrasyonunda ise $500 \mathrm{~nm}$ ile $1.5 \mu \mathrm{m}$ aralığında değişen boncuk yapıları gözlenmiştir (41).

\section{ELEKTROEĞRILMIŞ NANOLIFLERINN UYGULAMA ALANLARI}

\section{Elektroeğrilmiş Nanoliflerin İlaç Taşıyıcı Sistem Olarak Kullanımı}

Elektroeğrilmiş nanoliflerin etkin madde salım özellikleri etkin maddenin difüzyonu ve taşıyıcı polimerin degredasyonu ile belirlenmektedir (5). Ayrıca; polimer özelliği, farklı polimerlerin bir arada kullanılması, nanolif yüzeyinin kaplanması, etkin madde moleküllerinin katı fazdaki hali (polimorfizm) salım profillerinin oluşmasında etkilidir (7). Nanoliflerden etkin madde salım özelliklerini lifin yapısı da etkilemektedir. Yapılarına göre lifler; matriks tip lifler, depo tipi lifler ve yüzeyinde aktif bileşen içeren lifler şeklinde sınıflandırılabilirler. Matriks tip liflerde etkin madde polimer matriksinde homojen olarak dağılmıştır. Etkin madde salımı polimerden difüzyon ile gerçekleşir ve salınan miktar zamanla azalma eğilimi gösterir. Ayrıca burst salım da görülebilmektedir. Depo tipi liflerde etkin madde lifin çekirdek kısmında yer alır ve polimer bu çekirdeği kılıf gibi sarmaktadır. Bu tip lifler koaksiyel (ortak eksenli) elektroeğirme metoduyla veya polimer emülsiyonunun konvensiyonel elektroeğirme yöntemiyle birlikte kullanılması ile elde edilmektedir. Depo tipi lifler ise iki farklı şekilde bulunabilirler. Birinci durumda, saf etkin madde katı ya da çözelti halinde lif çekirdeğinde yer alır ve saf polimer kılıf çevresini sarmaktadır. Bu durumda eğer polimer kılıfı uniform ve yeterince kalın ise; terapötik ajanın difüzyonu nanolifin ömrü boyunca stabildir. İkinci durumda ise; lif çekirdeğinde etkin madde polimer matriksinde disperse olmuş haldedir ve etrafı polimer kılıf ile sarılmıştır. Bu durumda, etkin madde salım davranışı daha karmaşıktır ve üç aşamada gerçekleşmektedir. Daha yavaş olan birinci aşamada, etkin maddenin matriks çekirdekten kılıfa difüzyonu gerçekleşir. Kılıf kısmındaki etkin madde miktarı çekirdekteki ile kıyaslanabilir oranlara geldiği zaman ikinci aşamaya geçilmiş olur ve bütün bir yapı matriks sistem halini alır $(7,42)$. Etkin madde molekülleri, kendilerinden önceki moleküllerin difüzyon yolaklarını takip ederek difüze olurlar ve bu aşama birinci aşamaya göre daha hızlı gerçekleşir. Üçüncü aşamada ise salım hızı yavaşlamaktadır. Bunun nedenleri ise; i) Lifteki etkin madde miktarı azalmıştır ve daha da azalmaya devam etmektedir, ii) çekirdek kısmında bulunan etkin madde moleküllerinin difüze olabilmesi için kat etmesi gereken mesafenin fazla olmasıdır (43). Yüzeyinde aktif bileşen içeren lifler ise daha çok doku mühendisliğinde kullanılmaktadır. Liflerin yüzeyleri kimyasal ve fiziksel olarak biyoaktif moleküller ve ligantlar ile modifiye edilerek biyobenzer özellikteki lifler elde edilmektedir (7).

Elektroeğrilmiş nanolifler ile birçok etkin madde salım çalışması yapılmıştır. Sascha Maretschek ve ark. yaptığı bir çalışmada, hidrofilik bir protein olan sitokrom C' nin hidrofobik özellikteki PLLA lifden salım hızının hidrofilik kopolimer [PEI (polietilenimin) ve PLL (poli-L-lisin)] oranına göre değişimini incelemişlerdir. PEI ve PLL oranı arttıkça etkin madde salımının arttı̆̆ı gözlemlenmiştir. 
Ayrıca kullanılan hidrofobik polimer oranına bağlı olarak ani bir salım olmadan istenilen salım profiline ulaşılmıştır (30). Yapılan başka bir çalışmada biyobozunur polimer olan PLCL kullanılarak; i) etkin madde yüklü katman, ii) bariyer katmanı, iii) etkin madde yüklü ikinci katman, iv) taban katmanı olmak üzere çok katmanlı bir nanolif sistemi geliştirilmiştir. Çok katmanlı bu sistem için yapılan in vitro salım çalışmaları sonucunda salım hızı ve salım süresinin lif çapı ve tabakaların kalınlığı ile doğrudan ilişkili olduğu bulunmuştur. Birinci tabakadaki etkin maddenin hızlı salımı ve üçüncü tabakadaki etkin maddenin geciktirilmiş salımı ile ardışık kemoterapi sistemleri gibi gelişmiş kombine tedavilerin geliştirilebileceği düşünülmektedir (44).

\section{Elektroeğrilmiş Nanoliflerin Doku Mühendisliğinde Kullanımı}

Doku mühendisliği ya da rejeneratif tıp, doku ve organ fonksiyonlarını geliştirme, düzeltme ve yerine koyma amacıyla, canlı bilimi ve mühendislik ilkelerinin ve yeniliklerinin birleştiği multidisipliner bir alandır. Kurulduğundan bu yana doku mühendisliği, neo-organ/ dokuların tasarımı ve fabrikasyonunda hücre, iskelet (ekstraselüler matriks) ve biyoreaktör kombinasyonu temelinde ilerlemektedir. Çünkü organizmadaki her bir organ ve doku iskeleti içindeki fonksiyonel hücreler ve destek hücrelerinden oluşmaktadır. Sentetik ya da doğal biyomateryallerin bileşimi ve geliştirilen iskelet yapısının hücre çevresi ile etkileşimleri bu yapının akıbetini belirlemektedir. Ve temel amaç vücudun, doku mühendisliği ile geliştirilmiş yapay iskeleti "kendi" olarak taniyarak kendisini iyileştirebilmesi ve dolayısıyla "yeni ve doğal" fonksiyonel dokuların rejenerasyonunda kullanılmasıdır (13).

Yapay bir doku iskeleti; doğal iskeleti mutlaka taklit edebilmeli, biyouyumlu olmalı, fizyolojik olarak inert olmalı, hücre büyümesini sağlaması için gerekli üç boyutlu yapıya sahip olmalı, advers reaksiyona neden olmamalı ve hücreler ile etkileşim yeteneğinde olmalıdır (13). Örneğin embriyonik kök hücreleri, keratinositler ve hepatositler gibi çeşitli hücrelerin nanolif ağdaki kültürleri, doku mühendisliğinde kullanılan diğer materyallere göre nanoliflerin doku iskeletine benzer şekilde daha yüksek yüzey alanı/hacim oranına sahip olması nedeniyle yüksek yaşayabilirlik göstermektedir. Ayrıca liflerin yüzeyleri kimyasal ve fiziksel olarak biyoaktif moleküller ve ligantlar ile modifiye edilerek biyobenzer özellikteki liflerin elde edilme imkanı nanoliflerin doku mühendisliğinde kullanılma potansiyelini artıran faktörlerdendir (7).

Doku mühendisliğinde nanolifler kullanıldığı birçok çalışma yapılmıştır (45-52). Ku ve Park yaptıkları bir çalışmada; midyenin kateşolden kaynaklanan doğal adhezif yapısını inceleyerek bu özelliği vasküler doku mühendisliğinde kullanabileceklerini düşünmüşlerdir. $\mathrm{Bu}$ yapısal benzerliği sağlamak amacıyla da PCL nanolifin dış yüzeyini polidopamin (kateşol kaynağı) ile kaplamışlar ve çalışmaları sonucunda modifiye edilmemiş ve jelatin kaphı PCL nanoliflere kıyasla insan göbek kordonu veni endotel hücrelerinin (HUVECs) polidopamin kaplı nanoliflerde daha fazla adheze olduklarını ve canlılık oranının da daha fazla olduğunu göstermişlerdir (45).

Yapılan başka bir çalışmada biyomedikal implant olarak kullanılan termoplastik poliüretanın (TPU) in vivo hidrolitik, oksidatif ve enzim degredasyonu azaltılmaya ve hücrelerin nanolif ağda çoğaltılması amaçlanmıştır. $\mathrm{Bu}$ amaçla koaksiyel elektroeğirme kullanılarak çekirdek kısmı TPU olan ve kılıf kısmını kolajenin oluşturduğu bir sistem tasarlanmıştır. Sonuç olarak domuz iliak endotel hücre kültürünün (PIECs) kolajen/TPU sisteminde yüksek canlılık gösterdiği bulunmuştur (49).

Ayrıca doku mühendisliğive etkin madde salımözelliklerinin bir arada kullanıldığ çalışmalar da mevcuttur (53-58). Karavasili ve ark. kemik ve dental doku rejenerasyonu için hidroksiapatit $\left(\mathrm{Ca}_{10}\left(\mathrm{PO}_{4}\right)_{6}(\mathrm{OH})_{2}\right)$, indometazin ve ibuprofen içeren PCL lifleri tasarlamışlardır. İmplante materyalin inflamasyon yanıtı artırma ihtimaline karşın formülasyona indometazin ve ibuprofen eklenmiştir. Yapılan çalışmanın sonucunda indometazin ve ibuprofenin yaklaşık kırk dakika içerisinde büyük ölçüde salınımının tamamlandığ 1 ve yirmi bir günlük inkübasyon süresinin sonucunda lif yüzeyinde apetit oluştuğu gözlenmiştir (53). Doku mühendisliği ve etkin madde salım özelliklerinin beraber kullanıldığı bir başka çalışmada ise; yapay nanolif doku iskeletinden destek kök hücreleri ve büyüme faktörünün kontrollü salımı ile tendon onarımına katkısı incelenmiştir. Elde edilen bulgular sonucunda implante edilen yapay nanolif doku iskeletinde hücre canlılığ 1 ve büyüme faktörünün kontrollü salımı sağlanmış ve yeni bir rejeneratif tedavi şekli olarak gelecek vadettiği ifade edilmiştir (54). Yapılan bu çeşitli çalışmalar sonucu nanoliflerin doku mühendisliği alanında çok iyi bir gelecek vaat ettiği düşünülmektedir. 


\section{ELEKTROEĞRILMIŞ NANOLİFLERINN İN VİTRO TESTLERLE DEĞERLENDİRILMESI}

\section{Elektroeğrilmiş Nanoliflerin Karakterizasyonu}

Elektroeğrilmiş nanoliflerin morfolojik analizinde genellikle taramalı elektron mikroskobu ve geçirimli elektron mikroskobu kullanılmaktadır. Mikroskobik incelemede nanolif yüzey özellikleri ve nanolif yapısının tekdüzeliği gibi özelliklerinin yanı sıra nanolif çap ölçümleri de gerçekleştirilebilmektedir. Çap ölçümü için bir standart olmamakla birlikte elektron mikroskobu ile görüntülenen 50 ya da 100 adet nanolifin çap ölçümü yapılmakta ve ortalama değer hesaplanarak bulunmaktadır $(32-34,42,59)$.

Elektroeğrilmiş nanolif örneklerinin kimyasal bileşimi ve kullanılan polimer ile etkin maddelerin birbiri ile geçimliliği Fourier dönüşümlü kızılötesi spektroskopisi (FTIR) analizleri ile değerlendirilmektedir. X-ışııı kırınım yöntemi (XRD) ve diferansiyel taramalı kalorimetri (DSC) ile nanolif ağın içerisindeki etkin madde ve polimerik materyalin fiziksel durumları ve geçimliliği incelenebilmektedir $(32-35,42,59)$.

\section{Etkin Maddenin Enkapsülasyon Etkinliği ve Yükleme Kapasitesi}

Etkin madde enkapsülasyon etkinliğinin ve etkin madde yükleme kapasitesinin belirlenmesi için nanolif örneğinden ağırlığı bilinen miktarı alınır ve asetonitril, diklorometan, kloroform gibi polimeri çözebilen bir çözücü ile karıştırılır, nanolif ağın tamamen çözünmesi sağlanır. Daha sonra çözelti santrifüj edilerek ya da filtreden geçirilerek önceden belirlenmiş olan analiz yöntemi ile miktar tayini yapılır (32, 33)

\section{Çözünme Hızı Testi}

Nanolif materyallerin çözünme hızı testi nanolifin uygulanacağı vücut bölgesine göre değişiklik göstermektedir. Zhang ve ark, yapmış oldukları çalışmada servikal karsinomanın nüksetmesini engellemek amacı ile cerrahi operasyon sonrasında karsinomun alındığı bölgeye implante edilecek sodyum dikloroasetat ve okzaliplatin içeren PLLA nanolif ağı tasarlamışlardır. İn vitro çözünme hızı testlerini ise $10 \mathrm{~mL}$ fosfat tuzu tamponu ( $\mathrm{pH}$ 7.4) kullanarak $37^{\circ} \mathrm{C}$ 'de yatay çalkalayıcı ile yapmışlardır. Sink koşulu sağlamak amacıyla önceden belirtilen zaman aralıklarında 3’er $\mathrm{mL}$ numune çekmişler ve yerine taze tampon çözeltisinden alınan miktar kadar ilave etmişlerdir (33). Yapılan başka bir çalışmada yanık tedavisinde lokal olarak kullanılan asiatikozit yüklü çekirdek kısmını etkin madde kitozan karışımının ve kılıf kısmını sodyum aljinat ile polivinil alkolün oluşturduğu elektroeğrilmiş nanolifler üretilmiştir. Çözünme hızı testi için $200 \mathrm{mg}$ nanolif örneği bir erlen içerisindeki $10 \mathrm{~mL}$ fosfat tuzu tamponu $(\mathrm{pH}=7.4)$ içerisinde konmuş ve $37^{\circ} \mathrm{C}$ 'de 500 rpm hızda yatay çalkalayıcıda yapılmıştır. Miktar tayini için l'er mL örnek alınarak etkin madde miktarı belirlenmiştir (59). Oral yol ile uygulanan nanolif formülasyonlarının çözünme hızı testleri için ise çözünme hızı cihazları tercih edilebilmektedir. Illangakoon ve ark, antispazmodik etkinliği olan mebeverinin hızlı salımı için polivinilpirolidon ve pH duyarlı salımı için Eudragit L100-55 nanoliflerini hazırlamışlar ve paletli çözünme hızı cihazı ile $\mathrm{pH} 2.0$ ve pH 6.8 ortamlarında çalışmışlardır. Etkin madde yüklü nanolif ağından $50 \mathrm{mg}$ tartılarak 0 numaralı sert jelatin kapsüllere doldurulmuş ve $400 \mathrm{~mL}$ ortam hacmi, $50 \mathrm{rpm}$ dönü hızında çalışmışlardır. Numune alma hacmi ise $3 \mathrm{~mL}$ olarak belirlenmiştir (36). Akhgari ve ark. tarafından yapılan bir çalışmada ise indometazinin kolon ortamında salımını sağlayacak Eudragit RS100 ve Eudragit S100 bileşiminden oluşan nanolifleri hazırlanmıştır. Çözünme hızı testi sepet yöntemi ve $500 \mathrm{~mL} l i k$ flasklarda $100 \mathrm{~mL}$ çalışma ortamında ve $100 \mathrm{rpm}$ dönü hızında yürütülmüştür. Çözünme testi $\mathrm{pH}$ $1.2,6.4,6.8$ ve 7.4 olmak üzere farklı $\mathrm{pH}$ değerlerinde yapılmış ve numune hacmi olarak $1 \mathrm{~mL}$ belirlenmiştir (37). Deriye uygulanan nanolif formülasyonlarında ise Franz difüzyon hücreleri tercih edilebilmektedir. Vargas ve ark., Calendula officinalis bitkisi ektresinin çok dallanmış poligliserol ile nanoliflerini yara örtücü olarak geliştirmişlerdir. Çözünme hızı testi için Franz difüzyon hücresi kullanılmış ve alıcı faza $10 \mathrm{~mL}$ fosfat tuzu tamponu ( $\mathrm{pH}$ 7.4) konarak manyetik karıştırıcı üzerine yerleştirilmiştir. $2 \mathrm{~cm}$ çapında nanolif diski alınmış ve donör fazına bir ızgara filtrenin üzerine yerleştirilmiştir. Numune olarak alıcı fazdan $100 \mu \mathrm{L}$ alınmıştır (38).

\section{Islanabilirlik}

Elektroeğrilmiş nanoliflerin 1slanabilirliği temas açısı ölçümleri ile belirlenmektedir. Yaklaşık $5 \mu L^{\prime}$ lik bir damla nanolif ağının üzerine konur ve damlanın yatay yüzey ile yaptığı açı temas açısı ölçüm cihazı ile ölçülür (34).

\section{Mekanik Özelliklerin Belirlenmesi}

Nanolif materyallerin mekanik özellikleri genellikle tekstür analiz cihazları ile incelenmektedir. Bu yöntemle nanolife ait gerinim direnci, kırılma anındaki yüzde esneme miktarı ve elastik modül gibi mekanik özellikler belirlenebilir $(38,60)$. 
Nanoliflerin in vitro değerlendirilmeleri için incelenen bu testlere ilave olarak özellikle doku mühendisliği alanında geliştirilen formülasyonların degredasyon hızı, hücre adhezyonu, yayllımı ve proliferasyonu, sitotoksisitesi ve biyoadhezyon özellikleri incelenmelidir (32, 33, 38, 45, 49, $59,60)$.

\section{ELEKTROEĞRİLMİS NANOLİFLERİN STERILIZZASYONLARI}

Elektroeğrilmiş nanolifler farmasötik alanda oldukça revaçta olan ve hem ilaç taşıyıcı sistem olarak hem de doku mühendisliğinde kullanım potansiyeline sahip bir nanoteknoloji ürünüdür. İlaç taşıyıcı sistem olarak özellikle implante edilen ve yara-yanık gibi enfeksiyona açık bölgeler ile doğrudan temasta olan yara örtücü materyallerin steril olması gerekliliği doğmaktadır. Aynı şekilde doku mühendisliğinde kullanılan nanolif materyallerinin cerrahi bir operasyon ile vücut içine yerleştirilmesi yine steril olma zorunluluğu getirmektedir. Ancak elektroeğrilmiş nanoliflerin hazırlanmalarında kullanılan polimerik materyallerin sahip oldukları düşük camsı geçiş sıcaklıkları, düşük erime noktaları ve hidrolitik degredasyon mekanizmaları sterilizasyon yöntemi seçilmesinde sinırlamalar getirmektedir. Bu nedenle yüksek 1sı uygulamasının ve su kullanımının olmadığ 1 yöntemler ön plana çıkmaktadır $(61,62)$. Etilen oksit ile sterilizasyon oldukça etkili olmasına rağmen yöntemin toksik etkileri nedeniyle tercih edilmemektedir (61-63). Bir başka seçenek olan ve yüksek penetrasyon özelliğine sahip $\gamma$-radyasyon ile sterilizasyon nanoliflerin sterilizasyonu için değerlendirilebilir. Ancak $\gamma$-radyasyon ile sterilizasyon yönteminde en büyük problem ise polimerlerin molekül ağırlıklarında azalmanın görülebilmesidir. Bu da ilaç taşıyıcı sistemlerde etkin madde salım profilinde değişmelere yol açabilir. Aynı zamanda tasarlanan yapay iskelet materyalinin degredasyon hızında artışa neden olabilir (6163). Elektron demeti kullanılarak sterilizasyon yöntemi $\gamma$-radyasyona benzer bir şekilde iyonlarla sterilizasyon temeline dayanmaktadır ancak $\gamma$-radyasyona göre penetre olabilirliği daha düşük ve daha yüksek dozda uygulanması gerekmektedir. Sterilizasyon yönteminde bir başka yaklaşım hidrojen peroksit radikalleri (hidroksil ve hidroperoksil) ile yapılan gaz plazma yöntemidir. Gaz plazma kullanılarak kısa süreli ve toksik etkisi görülmeyen bir sterilizasyon işlemi yapılabilir. Gaz plazma ile özellikle cerrahi malzemelerin sterilizasyonunda tercih edilmektedir ve nanolif materyallerin sterilizasyonu için kullanılabileceği düşünülmektedir (6163). Elektroeğrilmiş nanoliflerin sterilizasyonu için mutlak bir yöntem yoktur. Ancak iyonlarla sterilizasyon ve gaz plazma ile sterilizasyon yöntemleri ön plana çıkmaktadır. Ön formülasyon çalışmalarında, geliştirilen formülasyonlarda yer alan etkin madde ve polimer özelliklerine göre olası sterilizasyon yöntemleri denenerek en ideali seçilmelidir.

\section{SONUÇ}

Farmasötik amaçlarla geliştirilen nanolifler ilaç taşıyıcı sistem ve doku mühendisliği alanları başta olmak üzere çok çeşitli kullanım alanlarına sahiptir. Ancak üretim tekniğinin kolaylığı, tekrar edilebilirliği ve ölçek büyütme basamakları düşünüldüğünde elektroeğirme yöntemi ile nanolif üretimi ön plana çıkmaktadır. Elektroeğrilmiş nanoliflerin sahip oldukları yüksek yüzey alanı/ hacim oranları, çok çeşitli etkin madde ve polimer kullanım imkanı, fiziksel özellikleri ve kolay üretilebilirliği gibi birçok parametre, elektroeğrilmiş nanoliflerin ilaç taşıyıcı sistem ve yapay iskelet üretiminde kullanım potansiyelini artırmaktadır. Elektroeğrilmiş nanoliflerin hem etkin madde salım profilini modifiye edebildiği hem de hücre büyümesine ve yayılmasina imkan verecek fizikokimyasal özelliklere sahip olduğu yapılan birçok çalışmada ortaya konmuştur. Ayrıca implante nanoliflerin ve yapay nanolif iskeletlerinin sterilizasyon işlemine uygun olmaları farmasötik alanda kullanım potansiyelini artırmaktadır. Elektroeğrilmiş nanoliflerin günümüzde üzerinde çalışmaya değer bir teknoloji olduğu ve aynı zamanda gelecek vaat ettiği söylenebilir. 
Application of electrospun nanofibers in drug delivery and tissue engineering

\section{ABSTRACT}

Nanofibers which have a longer length than its diameter are widely used in many areas i.e. drug delivery systems and tissue engineering because of their convenient surface area to volume ratio. Electrospinning is the most common method for processing nanofibers. The nanofibers that are processed by electrospinning are called electrospun nanofibers. During the process, physicochemical properties of electrospun nanofibers can be affected by different parameters including applied voltage, solution flow rate, distance between capillary and collector, polymer physicochemical properties. Drug release properties of electrospun nanofibers are determined by diffusion and polymer degradation. Additionally, nanofibers' types i.e. matrix types or reservoir types affect drug release properties. Since the physical properties of nanofibers allow researchers to produce an artificial extracellular matrix to mimic microenvironments of tissues, they are used in tissue engineering for regeneration and production of a new tissue or an organ. Biosimilar nanofibers, therefore, can be obtained by modifying surfaces of nanofibers. Findings of our study suggest that because of their biosimilar character and providing intended drug release profile, nanofibers have a promising potential in the future of tissue engineering research.

Keywords: biosimilar, tissue engineering, electrospinning, drug delivery systems, nanofiber

\section{KAYNAKLAR}

1. Ramakrishna S, Fujihara K, Teo W-E, Lim T-C, Ma Z. An Introduction to Electrospinning and Nanofibers. World Scientific Co, Singapore. 2005.

2. Goddard WAIII, Brenner D, Lyshevski SE, Lafrate GJ. Handbook of Nanoscience, Engineering, and Technology, Second Edition. Boca Raton, FL: CRC press. 2007.

3. Qufu Wei, Dan Tao YX. Functional Nanofibers and their Applications. Editor: Qufu W. Woodhead Publishing, Philadelphia. 2012.

4. Ko FK, Wan Y. Introduction to Nanofiber Materials. Cambridge University Press, Cambridge. 2014.

5. Hu X, Liu S, Zhou G, Huang Y, Xie Z, Jing X. Electrospinning of polymeric nanofibers for drug delivery applications. J Control Release 2014;185:12-21.

6. Travis J. Sill HA von R. Electrospinning: Applications in drug delivery and tissue engineering. Biomaterials 2008;29:19892006.

7. Yoo HS, Kim TG, Park TG. Surface-functionalized electrospun nanofibers for tissue engineering and drug delivery. Adv Drug Deliv Rev 2009; 61:1033-42.

8. Tort S, Acartürk F. Wound healing and electrospun wound dressings: Review. Turkiye Klin J Pharm Sci 2015;4:68-78.

9. Zhou J, O'Keeffe M, Liao G, Zhao F, Terhorst C, Xu B. Design and synthesis of nanofibers of self-assembled de novo glycoconjugates towards mucosal lining restoration and antiinflammatory drug delivery. Tetrahedron 2016;72:6078-83.

10. Goddard WAIII, Brenner D, Lyshevski SE, Lafrate GJ. Handbook of Nanoscience, Engineering, and Technology, Third Edition. Boca Raton, FL: CRC press. 2012.

11. Zhou T, Zhu B, Chen F, Liu Y, Ren N, Tang J, Ma X, Su Y, Zhu $\mathrm{X}$. Micro-/nanofibers prepared via co-assembly of paclitaxel and dextran. Carbohydr Polym 2017;157:613-9.

12. Kang J, Gi H, Choe R, Yun SI. Fabrication and characterization of poly(3-hydroxybutyrate) gels using non-solvent-induced phase separation. Polym (United Kingdom) 2016;104:61-71.

13. Barnes CP, Scott AS, Sell SA, Boland ED, Simpson DG, Bowlin GL. Nanofiber technology: Designing the next generation of tissue engineering scaffolds. Adv Drug Deliv Rev 2007;59:1413-33.

14. Bhardwaj N, Kundu SC. Electrospinning: A fascinating fiber fabrication technique. Biotechnol Adv 2010;28:325-47.

15. Deitzel J, Kleinmeyer J, Harris D, Beck Tan N. The effect of processing variables on the morphology of electrospun nanofibers and textiles. Polymer (Guildf) 2001;42:261-72.

16. Reneker $\mathrm{DH}$ and Chun I. Nanometre diameter fibres of polymer, produced by electrospinning. Nanotechnology 1996;7:216-23.

17. Zhang C, Yuan X, Wu L, Han Y, Sheng J. Study on morphology of electrospun poly(vinyl alcohol) mats. Eur Polym J 2005;41:423-32.

18. Demir M, Yilgor I, Yilgor E, Erman B. Electrospinning of polyurethane fibers. Polymer (Guildf) 2002;43:3303-9.

19. Megelski S, Stephens JS, Chase DB, Rabolt JF. Micro- and nanostructured surface morphology on electrospun polymer fibers. Am Chem Soc 2002;35:8456-66.

20. Haghi AK, Akbari M. Trends in electrospinning of natural nanofibers. Phys status solidi 2007;204:1830-4.

21. Taylor G. Electrically Driven Jets. Proc R Soc London A Math Phys Eng Sci 1969;313.

22. Zong X, Kim K, Fang D, Ran S, Hsiao BS, Chu B. Structure and process relationship of electrospun bioabsorbable nanofiber membranes. Polymer (Guildf) 2002;43:4403-12.

23. Kim KH, Jeong L, Park HN, Shin SY, Park WH, Lee SC, Kim TL, Park YJ, Seol YJ, Lee YM, Ku Y, Rhyu IC. Biological efficacy of silk fibroin nanofiber membranes for guided bone regeneration. J Biotechnol 2005;120:327-39.

24. Wannatong L, Sirivat A, Supaphol P. Effects of solvents on electrospun polymeric fibers: preliminary study on polystyrene. Polym Int 2004;53:1851-9.

25. Yuan X, Zhang Y, Dong C, Sheng J. Morphology of ultrafine polysulfone fibers prepared by electrospinning. Polym Int 2004;53:1704-10.

26. Ki CS, Baek DH, Gang KD, Lee KH, Um IC, Park YH. Characterization of gelatin nanofiber prepared from gelatinformic acid solution. Polymer (Guildf) 2005;46:5094-102. 
27. Geng X, Kwon OH, Jang J. Electrospinning of chitosan dissolved in concentrated acetic acid solution. Biomaterials 2005;26:5427-32.

28. Doshi J, Reneker DH. Electrospinning process and applications of electrospun fibers. J Electrostat 1995;35:151-60.

29. Zeng J, Haoqing H, Schaper A, Wendorff JH, Greiner A. Poly-L-lactide nanofibers by electrospinning - Influence of solution viscosity and electrical conductivity on fiber diameter and fiber morphology. e-Polymers 2003;3:102-10.

30. Tan SH, Inai R, Kotaki M, Ramakrishna S. Systematic parameter study for ultra-fine fiber fabrication via electrospinning process. Polymer (Guildf) 2005;46:6128-34.

31. Hohman MM, Shin M, Rutledge G, Brenner MP. Electrospinning and electrically forced jets. II. Applications. Physics of Fluids 2001;3:2221-36.

32. Wang B, Li H, Yao Q, Zhang Y, Zhu X, Xia T, Wang J, Li G, Li $\mathrm{X}, \mathrm{Ni}$ S. Local in vitro delivery of rapamycin from electrospun PEO/PDLLA nanofibers for glioblastoma treatment. Biomed Pharmacother 2016;83:1345-52.

33. Zhang Z, Liu S, Qi Y, Zhou D, Xie Z, Jing X, Chen X, Huang Y. Time-programmed DCA and oxaliplatin release by multilayered nanofiber mats in prevention of local cancer recurrence following surgery. J Control Release 2016;235:12533.

34. Sun X, Li K, Chen S, Yao B, Zhou Y, Cui S, Hu J, Liu Y. Rationally designed particle preloading method to improve protein delivery performance of electrospun polyester nanofibers. Int J Pharm 2016;512:204-12.

35. Huang LY, Branford-White C, Shen XX, Yu DG, Zhu LM. Time-engineeringed biphasic drug release by electrospun nanofiber meshes. Int J Pharm 2012;436:88-96.

36. Illangakoon UE, Nazir T, Williams GR, Chatterton NP. Mebeverine-loaded electrospun nanofibers: Physicochemical characterization and dissolution studies. J Pharm Sci 2014;103:283-92.

37. Akhgari A, Heshmati Z, Afrasiabi Garekani H, Sadeghi F, Sabbagh A, Sharif Makhmalzadeh B-S, Nokhodchi A. Indomethacin electrospun nanofibers for colonic drug delivery: In vitro dissolution studies. Colloids Surfaces B Biointerfaces 2017;152:29-35.

38. Vargas E.A-T, do Vale Baracho NC, de Brito J, de Queiroz A.A.A. Hyperbranched polyglycerol electrospun nanofibers for wound dressing applications. Acta Biomater 2010;6:106978 .

39. Hayati I, Bailey AI, Tadros TF. Investigations into the Mechanisms of Electrohydrodynamic Spraying of Liquids I. Effect of electric field and the environment on pendant drops and factors affecting the formation of stable jets and atomization. J Colloid Interface Sci 1987 1;117:205-21.

40. Akhgari A, Heshmati Z, Sharif Makhmalzadeh B. Indomethacin electrospun nanofibers for colonic drug delivery: preparation and characterization. Adv Pharm Bull 2013;3:85-90.

41. Jahangiri A, Davaran S, Fayyazi B, Tanhaei A, Payab S, Adibkia K. Application of electrospraying as a one-step method for the fabrication of triamcinolone acetonide-PLGA nanofibers and nanobeads. Colloids Surfaces B Biointerfaces 2014;123:21924.
42. Xu X, Chen X, Ma PA, Wang X, Jing X. The release behavior of doxorubicin hydrochloride from medicated fibers prepared by emulsion-electrospinning. Eur J Pharm Biopharm 2008;70:165-70.

43. Maretschek S, Greiner A, Kissel T. Electrospun biodegradable nanofiber nonwovens for controlled release of proteins. J Control Release 2008;127:180-7.

44. Okuda T, Tominaga K, Kidoaki S. Time-programmed dual release formulation by multilayered drug-loaded nanofiber meshes. J Control Release 2010;143:258-64.

45. $\mathrm{Ku} \mathrm{SH}$, Park CB. Human endothelial cell growth on musselinspired nanofiber scaffold for vascular tissue engineering. Biomaterials 2010;31:9431-7.

46. Zhu Y, Leong MF, Ong WF, Chan-Park MB, Chian KS, Esophageal epithelium regeneration on fibronectin grafted poly(l-lactide-co-caprolactone) (PLLC) nanofiber scaffold. Biomaterials 2007;28:861-8.

47. Lee CH, Shin HJ, Cho IH, Kang Y-M, Kim IA, Park K-D, Shin J-W. Nanofiber alignment and direction of mechanical strain affect the ECM production of human ACL fibroblast. Biomaterials 2005;26:1261-70.

48. Jang YS, Jang CH, Cho YB, Kim M, Kim GH. Tracheal regeneration using polycaprolactone/collagen-nanofiber coated with umbilical cord serum after partial resection. Int J Pediatr Otorhinolaryngol 2014;78:2237-43.

49. Chen R, Huang C, Ke Q, He C, Wang H, Mo X. Preparation and characterization of coaxial electrospun thermoplastic polyurethane/collagen compound nanofibers for tissue engineering applications. Colloids Surf B Biointerfaces 2010;79:315-25.

50. Şenel Ayaz HG, Perets A, Ayaz H, Gilroy KD, Govindaraj M, Brookstein D, Lelkes PI. Textile-templated electrospun anisotropic scaffolds for regenerative cardiac tissue engineering. Biomaterials 2014;35:8540-52.

51. Chua K-N, Lim W-S, Zhang P, Lu H, Wen J, Ramakrishna S, Leong KW, Mao HQ. Stable immobilization of rat hepatocyte spheroids on galactosylated nanofiber scaffold. Biomaterials 2005;26:2537-47.

52. He X, Cheng L, Zhang X, Xiao Q, Zhang W, Lu C. Tissue engineering scaffolds electrospun from cotton cellulose. Carbohydr Polym 2015;115:485-93.

53. Karavasili C, Bouropoulos N, Kontopoulou I, Smith A, van der Merwe SM, Rehman IUR, Ahmad Z, Fatouros DG. Preparation and characterization of multiactive electrospun fibers: Poly- $\square$ carpolactone fibers loaded with hydroxyapatite and selected NSAIDs. J Biomed Mater Res Part A 2014;102:2583-9.

54. Manning CN, Schwartz AG, Liu W, Xie J, Havlioglu N, Sakiyama-Elbert SE, Silva MJ, Xia Y, Gelberman RH, Thomopoulos S. Controlled delivery of mesenchymal stem cells and growth factors using a nanofiber scaffold for tendon repair. Acta Biomater 2013;9:6905-14.

55. Kolambkar YM, Dupont KM, Boerckel JD, Huebsch N, Mooney DJ, Hutmacher DW, Guldberg RE. An alginate-based hybrid system for growth factor delivery in the functional repair of large bone defects. Biomaterials 2011;32:65-74.

56. Saravanabhavan SS, Dharmalingam S. Fabrication of polysulphone/hydroxyapatite nanofiber composite implant and evaluation of their in vitro bioactivity and biocompatibility 
towards the post-surgical therapy of gastric cancer. Chem Eng J 2013;234:380-8.

57. Xue J, He M, Liu H, Niu Y, Crawford A, Coates PD, Chen D, Shi R, Zhang L. Drug loaded homogeneous electrospun PCL/gelatin hybrid nanofiber structures for anti-infective tissue regeneration membranes. Biomaterials 2014;35:9395405.

58. Ionescu LC, Lee GC, Sennett BJ, Burdick JA, Mauck RL. An anisotropic nanofiber/microsphere composite with controlled release of biomolecules for fibrous tissue engineering. Biomaterials 2010;31:4113-20.

59. Zhu L, Liu X, Du L, Jin Y. Preparation of asiaticoside-loaded coaxially electrospinning nanofibers and their effect on deep partial-thickness burn injury. Biomed Pharmacother 2016;83:33-40.
60. Tort S, Acartürk F. Preparation and characterization of electrospun nanofibers containing glutamine. Carbohydr Polym 2016;152:802-14.

61. Rediguieri CF, Sassonia RC, Dua K, Kikuchi IS, de Jesus Andreoli Pinto T. Impact of sterilization methods on electrospun scaffolds for tissue engineering. Eur Polym J 2016;82:181-95.

62. Rainer A, Centola M, Spadaccio C, Gherardi G, Genovese JA, Licoccia S, Trombetta M. Comparative study of different techniques for the sterilization of poly-L-lactide electrospun microfibers: Effectiveness vs. material degradation. Int J Artif Organs 2010;33:76-85.

63. Holy CE, Cheng C, Davies JE, Shoichet MS. Optimizing the sterilization of PLGA scaffolds for use in tissue engineering. Biomaterials 2001;22:25-31. 